
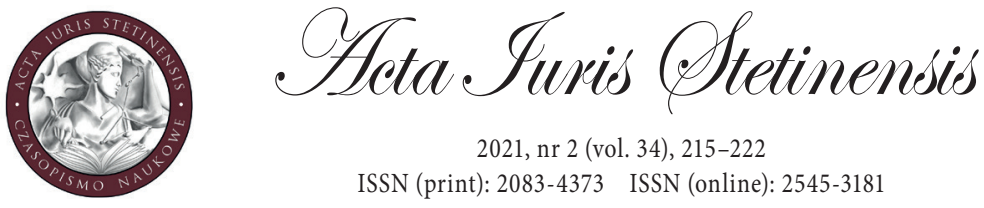

2021, nr 2 (vol. 34), 215-222

ISSN (print): 2083-4373 ISSN (online): 2545-3181

DOI: $10.18276 /$ ais.2021.34-13

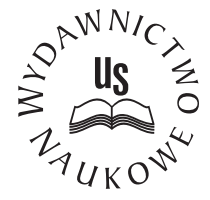

Rafał Dowgier

dr hab. prof. UwB

OPEN ACCESS

Uniwersytet w Białymstoku

e-mail: r.dowgier@uwb.edu.pl

(c) (i) (2)

ORCID: 0000-0003-1583-086X

\title{
Małgorzata Ofiarska, Zbigniew Ofiarski, Fundusz dróg samorządowych. Komentarz Wolters Kluwer, Warszawa 2020
}

\author{
ISBN 978-83-8187-105-1, ss. 336
}

Komentowanie regulacji prawnych w dzisiejszych, bardzo dynamicznych z punktu widzenia działań legislacyjnych czasach, jest dość ryzykowne. Przepisy zmieniają się tak szybko, co w ostatnim czasie zasadniczo tłumaczone jest koniecznością walki z pandemią wirusa SARS-CoV-2, że niekiedy trudno jest za tymi zmianami nadążyć. Komentarze do ustaw dezaktualizują się już w trakcie pisania lub zaraz po ich napisaniu. Na szczęście większość zmian nie ma charakteru zasadniczego, a stanowią one $\mathrm{w}$ dużej mierze wyraz doraźnych potrzeb związanych z funkcjonowaniem systemu prawnego.

We wstępie do recenzowanego opracowania wskazano, że uwzględnia ono stan prawny obowiązujący na dzień 25 października 2019 roku. W tej dacie Autorzy komentowali ustawę z dnia 23 października 2018 roku o Funduszu Dróg 
Samorządowych ${ }^{1}$. Jednak na mocy nowelizacji dokonanej z dniem 31 grudnia 2020 roku $^{2}$ wskazana ustawa otrzymała nową, lepszą w ocenie ustawodawcy nazwę. Aktualnie akt ten dotyczy Rządowego Funduszu Rozwoju Dróg. Zasadnicze cele Funduszu pozostały bez zmian, ale jak wskazano w uzasadnieniu do projektu nowelizacji, „Omawiana zmiana ma na celu zaakcentowanie roli jaką ma Fundusz jako podstawowe wsparcie finansowe dla realizacji inwestycji w infrastrukturę lokalną, szczególnie po planowanym objęciu dofinansowaniem zadań obwodnicowych i zadań obejmujących wyłącznie poprawę bezpieczeństwa na przejściach dla pieszych. Są to bowiem zadania, które w niewątpliwy sposób pozytywnie wpływają na rozwój dróg oraz poziom bezpieczeństwa drogowego. Zwiększenie bezpieczeństwa w ruchu drogowym i rozwój dróg jest zaś priorytetem Rady Ministrów”. Z pewnością wskazane cele są też priorytetem samorządu, ale zmiana ustawy miała, jak się wydaje, podkreślić, że finansowanie następuje poprzez fundusz państwowy. Nie jest to argument przekonujący. Słusznie bowiem we wprowadzeniu do komentarza wskazuje się na $\$ 16$ rozporządzenia Prezesa Rady Ministrów z dnia 20 czerwca 2002 roku w sprawie „Zasad techniki prawodawczej”, zgodnie z którym tytuł ustawy powinien odzwierciedlać jej przedmiot. Pomimo zmiany nazwy analizowanego aktu bez zmian pozostaje jego przedmiot - reguluje on problematykę wyodrębnionego funduszu celowego, którego środki są przeznaczone na realizację zadań w zakresie budowy, przebudowy lub remontu dróg gminnych, powiatowych oraz wojewódzkich i budowy mostów zlokalizowanych w ciągu tych dróg. Po nowelizacji finansowanie z Funduszu objęło również budowę obwodnic zlokalizowanych w ciągu wskazanych dróg, a także inwestycje na drogach zarządzanych przez prezydentów miast na prawach powiatu będących siedzibą wojewody lub sejmiku województwa. Rozszerzenie zakresu ustawy nie zmieniło istoty jej regulacji, stąd z pewnością nie było merytorycznych przesłanek do zmiany samej nazwy Funduszu, jak i tytułu ustawy, która reguluje jego funkcjonowanie.

Pomimo tego, że analizowana ustawa po opublikowaniu komentarza została znowelizowana, to $\mathrm{w}$ zasadniczej części pozostaje on nadal aktualny. Już w tym miejscu docenić należy wysiłek Autorów związany nie tylko z analizą szczegółowych rozwiązań z zakresu finansowania inwestycji w zakresie dróg samorządowych, lecz także z szerszym kontekstem finansów publicznych. Pozwalają one zrozumieć ogólne mechanizmy związane z finansowaniem zadań samorządowych. Świadczy

1 Dz.U. poz. 2161 ze zm.

2 Ustawa z dnia 19 listopada 2020 r. o zmianie ustawy o Funduszu Dróg Samorządowych oraz niektórych innych ustaw (Dz.U. poz. 2338).

3 Tekst jedn. Dz.U. z 2016 r., poz. 283 ze zm. 
to też o rozległej wiedzy Autorów, których zainteresowania badawcze znacznie wykraczają poza zakres komentowanej ustawy. Należy jednak docenić, że znaleźli czas na podjęcie tej z perspektywy praktyki niezmiernie ważnej problematyki.

Zasadnicze z punktu widzenia komercyjnego wydawcy publikacji książkowych znaczenie mają takie elementy jak trafność podjętej problematyki oraz jej oryginalność na rynku wydawniczym, a także walory praktyczne. Skoro więc wydawnictwo Wolters Kluwer zdecydowało się opublikować w wersji papierowej przedmiotowy komentarz (aktualnie taka wersja nie jest wcale oczywista, gdyż ilość zmian w przepisach przemawia za przygotowaniem łatwych do aktualizacji opracowań elektronicznych), to wskazane kryteria uznało za spełnione. W mojej ocenie tak właśnie jest - mamy do czynienia z opracowaniem dotyczącym stosunkowo nowego aktu prawnego, który nie doczekał się do tej pory omówienia. I pewnie w najbliższym czasie nikt, poza Autorami recenzowanego komentarza, tą problematyką nie będzie się szerzej zajmował, ponieważ wyczerpali przedmiotową problematykę, oczywiście $\mathrm{w}$ zakresie stanu prawnego sprzed nowelizacji. Zmiany $\mathrm{z}$ łatwością mogą być jednak uwzględnione przy kolejnym wydaniu komentarza, bo zainteresowanie nim z pewnością będzie duże. I w tym miejscu warto postawić pytanie o to, do kogo opracowanie jest adresowane? Przede wszystkim widzę dwie grupy takich odbiorców. W pierwszej kolejności będą to osoby odpowiedzialne za przygotowanie w jednostkach samorządu terytorialnego wniosków o dofinansowane. Chodzi tutaj nie tylko o pracowników właściwych urzędów, ale także profesjonalnych pełnomocników (radców prawnych, adwokatów), którzy prowadzą obsługę prawną jednostek samorządu terytorialnego. Drugą zasadniczą grupą adresatów komentarza będą osoby odpowiedzialne za weryfikację wniosków oraz przyznawanie dofinansowania. Nie może też umknąć uwadze fakt, że mamy do czynienia ze sprawami finansowymi, które podlegają nadzorowi regionalnych izb obrachunkowych. Idąc dalej, rozstrzygnięcia nadzorcze izb podlegają zaskarżeniu do sądów administracyjnych, co wskazuje na kolejną kategorię podmiotów, które mogą być zainteresowane omawianym komentarzem.

$\mathrm{Za}$ racji wykonywanego zawodu nie mogę też nie wspomnieć o wpływie komentarza na naukę prawa finansów publicznych. Nie jest przecież tak, że istnieje zupełny rozdział teorii od praktyki, a wręcz przeciwnie, uważam, że obszary te wzajemnie się przenikają. Komentarz jest tego dowodem. Zrozumienie omówionych w nim mechanizmów wymaga niekiedy nie tylko dobrej znajomości szczegółowych regulacji ustawy dotyczącej Funduszu, lecz także szerszego kontekstu finansowania 
zadań publicznych, w tym finansowania pozabudżetowego ${ }^{4}$. I odwrotnie - konkretne rozwiązania omówione $\mathrm{w}$ komentarzu pozwalają zrozumieć podstawowe mechanizmy funkcjonowania finansów publicznych.

Reasumując tę część recenzji, z pełnym przekonaniem należy stwierdzić, że mamy do czynienia z opracowaniem przede wszystkim z punktu widzenia praktyki potrzebnym. Przedstawione przez Autorów zagadnienia są stosunkowo nowe i nie doczekały się do tej pory opracowania o charakterze monograficznym. Pozwala to postawić tezę, że komentarz spotka się z dużym zainteresowaniem osób, które zetkną się $\mathrm{w}$ różnych aspektach z problematyką finansowania samorządowych inwestycji drogowych.

Przed bardziej szczegółowym odniesieniem się do merytorycznych wartości opracowania, należy poruszyć kwestie formalne. W tym aspekcie gwarantem wysokiego poziomu wydawniczego jest renomowane wydawnictwo Wolters Kluwer Polska Sp. z o.o. Publikacja ukazała się w serii wydawniczej „Komentarze Praktyczne” i posiada znany już i doceniany na rynku układ. Szczegółowa analiza przepisów poprzedzona jest wprowadzeniem, w którym Autorzy przedstawiają m.in. przyczyny uchwalenia komentowanej regulacji, cel opracowania oraz sposób przedstawienia analizowanej materii.

Sam komentarz opiera się na usystematyzowanym omówieniu kolejnych przepisów ustawy. Warto zwrócić uwagę na to, że w ramach bardziej rozbudowanych jednostek redakcyjnych aktu, Autorzy podzielili swoje rozważania na części, z zasady poprzedzone uwagami wprowadzającymi. Ich celem jest ogólne wprowadzenie do bardziej szczegółowej problematyki zasadniczo poprzez przedstawienie zakresu danej regulacji (artykułu). Podział treści merytorycznych na części sprzyja przede wszystkim poruszaniu się czytelnika $\mathrm{w}$ gąszczu wielu zagadnień. Prezentowane wywody są dzięki temu uporządkowane i przejrzyste. Myślę, że pomimo tego, iż nie mamy do czynienia $z$ komentarzem nazbyt obszernym, dodatkowym atutem wydania mogłoby być sporządzenie indeksu rzeczowego, który w jeszcze większym stopniu ułatwiłby czytelnikom odszukanie interesujących ich zagadnień.

Komentarz kończą wykazy aktów prawnych, orzecznictwa oraz bibliografii. Nawet ich pobieżna analiza świadczyć może o dwóch rzeczach. Po pierwsze, wykorzystanie w szerokim zakresie orzecznictwa sądów, a także rozstrzygnięć nadzorczych, potwierdza praktyczny aspekt opracowania. Po drugie, wykorzystana $\mathrm{w}$ pracy literatura przedmiotu pozwala stwierdzić, że Autorzy na tle komentowanej ustawy odnoszą się również do innych zagadnień, których znajomość jest

4 Problematyka ta była dość szeroko omówiona w literaturze przedmiotu - zob. np. J. Stankiewicz, Debudżetyzacja finansów państwa, Białystok 2007. 
niezbędna do jej zrozumienia. Będzie o tym jeszcze mowa w dalszej części recenzji, ale już teraz trzeba podkreślić, że komentarz wymagał w wielu miejscach sięgnięcia do przepisów, do których ustawa wprost odsyła, albo też takich, do których nie odsyłała, ale ich znajomość była konieczna z systemowego punktu widzenia. Sprawia to, że w niektórych fragmentach opracowanie poszerza czytelnikowi horyzonty o zagadnienia, które z samą ustawą nie muszą mu się kojarzyć (np. regulacje dotyczące Banku Gospodarstwa Krajowego).

Nie może umknąć ocenie także sposób przekazu prezentowany przez Autorów. Zagadnienia przedstawione $\mathrm{w}$ komentarzu są ze swej natury złożone, ale przedstawiono je w sposób przystępny i klarowny. Nadużyciem byłoby może stwierdzenie, że prezentowane wywody będą zrozumiałe nawet dla osób, które z prawem, a w szczególności prawem finansowym, nigdy nie miały do czynienia, ale chyba nie do takich podmiotów są one adresowane. Natomiast, gdy ktoś mający konkretny problem sięgnie do komentarza, $\mathrm{z}$ dużym prawdopodobieństwem znajdzie wskazówki dotyczące sposobu jego rozwiązania. Należy to docenić, gdyż niekiedy komentatorzy ograniczają się do stawiania pytań, nie udzielając na nie (zwłaszcza gdy są trudne) odpowiedzi. Takiej sytuacji w recenzowanym komentarzu nie odnotowałem, gdyż jego Autorzy nie tylko prezentowali określone problemy, stawiali pytania, ale też poszukiwali na nie odpowiedzi.

Reasumując, stwierdzić należy, że $\mathrm{w}$ aspekcie formalnym recenzowane opracowanie nie budzi żadnych zastrzeżeń. Jest to klasyczny komentarz do ustawy, skonstruowany w przejrzysty sposób i wyposażony w niezbędne elementy źródłowe. Również w sferze języka prowadzonych rozważań trudno jest wskazać na jakiekolwiek mankamenty.

Już we wprowadzeniu do komentarza jego Autorzy w zarysie prezentują problematykę, która została w nim omówiona. System finansowania inwestycji drogowych z funduszu celowego zastąpił obowiązujące do tej pory dofinansowanie poprzez dotacje celowe $\mathrm{z}$ budżetu państwa wypłacane $\mathrm{w}$ ramach wieloletnich programów, rozszerzając przy tym jego zakres. Finansowanie obejmuje aktualnie, po przemianowaniu Funduszu Dróg Samorządowych na Rządowy Fundusz Rozwoju Dróg, nie tylko projekty w zakresie inwestycji i remontów dróg i mostów, lecz także obwodnic. W porównaniu do stanu sprzed powołania Funduszu zmianie uległy także podstawowe przesłanki wysokości udzielonego finansowania, które uzależniono od potencjału dochodowego jednostki samorządu terytorialnego.

Autorzy słusznie podkreślają, co jest wymiernym argumentem przemawiającym za istotnym praktycznym znaczeniem recenzowanej pracy, jak duże środki finansowe w ostatnich latach przeznaczane były na finansowanie samorządowej infrastruktury drogowej. Planując funkcjonowanie Funduszu Dróg Samorządowych na 10 lat, przewidziano jego łączne wydatki na kwotę 42,8 mln zł. 
Warto też zwrócić uwagę na szeroką perspektywę prowadzonych w komentarzu rozważań. W szczególności podkreślić należy, że Autorzy nie uciekają, w zakresie do tego niezbędnym, od analizy aktów, do których odsyła komentowana ustawa. Prezentują więc wybrane zagadnienia z zakresu m.in. ustaw z dnia: 20 czerwca 1997 roku - Prawo o ruchu drogowym ${ }^{5}$ (komentarz do art. 2), 1 grudnia 1995 roku o wpłatach zysku przez jednoosobowe spółki Skarbu Państwa ${ }^{6}$ (komentarz do art. 2), 27 kwietnia 2001 roku - Prawo ochrony środowiska ${ }^{7}$ (komentarz do art. 5), 27 sierpnia 2009 roku o finansach publicznych ${ }^{8}$ (komentarz do art. 5) czy też ustawy z dnia 29 sierpnia 1997 roku - Ordynacja podatkowa ${ }^{9}$ (komentarz do art. 5). Realizacji wskazanego na wstępie celu służy także przedstawienie regulacji prawnych, do których wprawdzie komentowana ustawa wprost nie odsyła, ale które z pewnością mają znaczenie z punktu widzenia stosowania jej przepisów. Mam tutaj na myśli przede wszystkim rozważania zawarte w komentarzu do art. 13, odnoszące się do zasad funkcjonowania i obsługi Funduszu przez Bank Gospodarstwa Krajowego.

Objętość opracowania wynosi ponad 300 stron, co z uwagi na niezbyt obszerną regulację ustawową wskazuje na to, że jego Autorzy w dość szczegółowym zakresie analizowali problematykę Funduszu Dróg Samorządowych. Jak już wcześniej podniesiono, nie pominęli przy tym szerszego kontekstu powołania i prowadzenia tego funduszu wynikającego przede wszystkim $\mathrm{z}$ regulacji ustawy o finansach publicznych. $W$ tym zakresie zwrócić należy uwagę na interesujące rozważania zawarte w komentarzu do art. 3, w których Autorzy omawiają zastosowanie do tego funduszu celowego zasad określonych $\mathrm{w} w w$. ustawie, $\mathrm{w}$ tym $\mathrm{w}$ zakresie jego powołania, wyodrębnienia z budżetu państwa, zasad gromadzenia i wydatkowania zgromadzonych w nim środków.

W kontekście ostatnich miesięcy interesujący jest prezentowany w komentarzu do art. 5 (pkt 5) wątek finansowania Funduszu ze środków pochodzących z wpłat od jednoosobowych spółek Skarbu Państwa. Zauważyć bowiem trzeba, że status podmiotów zobowiązanych do wpłat mają także spółki Skarbu Państwa, takie jak publiczne rozgłośnie radiowe i stacje telewizyjne finansowane w znacznym stopniu $\mathrm{z}$ opłat abonamentowych oraz rekompensaty $\mathrm{z}$ tytułu utraconych środków abonamentowych. Jak argumentuje Szef Rady Mediów Narodowych, nadwyżka przychodów pochodzących ze źródeł wskazanych art. 31 ust. 1 i ust. 2 ustawy z dnia

5 Tekst jedn. Dz.U. z 2020 r., poz. 110 ze zm.

6 Tekst jedn. Dz.U. z 2020 r., poz. 16 ze zm.

7 Tekst jedn. Dz.U. z 2020 r., poz. 1219 ze zm.

8 Tekst jedn. Dz.U. z 2019 r., poz. 869 ze zm.

9 Tekst jedn. Dz.U. z 2019 r., poz. 900 ze zm. 
29 grudnia 1992 roku o radiofonii i telewizji ${ }^{10}$, przekraczająca koszt netto realizacji misji publicznej w przypadku nieprzeznaczenia ich na realizację misji publicznej, spółki zobowiązane są zwrócić do Krajowej Rady Radiofonii i Telewizji ${ }^{11}$. Z tego powodu kwestionuje on zasadność dokonywania przez te spółki wpłat na Fundusz. Jest to zagadnienie, które z pewnością będzie w najbliższym czasie rozważane i jest warte szerszego omówienia w kolejnych wersjach recenzowanego komentarza.

Z zagadnieniem wpłat dokonywanych przez spółki Skarbu Państwa koresponduje także dualizm prawny wynikający $\mathrm{z}$ zastosowania $\mathrm{w}$ odniesieniu do nich wybranych regulacji ustawy Ordynacja podatkowa, ale też ustawy o finansach publicznych. Problem ten dostrzegany jest $\mathrm{w}$ literaturze przedmiotu ${ }^{12}$, chociaż w tym przypadku chodzi o wpłaty dokonywane przez spółki na rzecz funduszu celowego. Przyjąć należy, że wobec brzmienia art. 2 ordynacji podatkowej wskazującego na zastosowanie jej przepisów do niepodatkowych należności budżetowych, do których ustalania lub określania właściwe są organy podatkowe (w przypadku wpłat na Fundusz jedynie uprawnienia organów podatkowych przysługują ministrowi właściwemu do spraw transportu), art. 5 ust. 5 komentowanej ustawy wyznacza granice posługiwania się tym aktem.

Duże wrażenie robi ta część komentarza, w której Autorzy przedstawili zasady obsługi bankowej Funduszu (art. 13). Widać w tym miejscu, że ich wiedza wychodzi daleko poza granice wyznaczone li tylko omawianą ustawą. Zaprezentowane rozważania odnoszą się zarówno do regulacji ustawy o finansach publicznych, jak i prawa bankowego. Szczegółowej analizie poddano także zakres i istotę obsługi bankowej Funduszu przez Bank Gospodarstwa Krajowego.

Zasadniczą część komentarza stanowią rozważania dotyczące zasad udzielania dofinansowania i finansowania ze środków Funduszu. Również w tym zakresie trzeba podkreślić, że prezentowane treści są adekwatne do analizowanej materii, która w pewnych obszarach jest dość skomplikowana, a ponadto ma duże znaczenie praktyczne. W tym ostatnim aspekcie należy zauważyć, że w komentarzu w dość przystępny sposób omówiono poszczególne etapy procedury wnioskowania o dofinansowanie, poczynając od złożenia wniosku, poprzez jego ocenę, a na zawarciu umowy o udzielenie dofinansowania skończywszy. Szczegółowo odniesiono się

10 Tekst jedn. Dz.U. z 2020 r., poz. 805.

11 www.wirtualnemedia.pl/artykul/publiczne-media-oplata-fundusz-drog-samorzadowych (dostęp 14.03.2020).

12 Zob. M. Popławski, Komentarz do art. 2, w: L. Etel (red.), R. Dowgier, P. Pietrasz, M. Popławski, S. Presnarowicz, W. Stachurski, K, Teszner, Ordynacja podatkowa. Komentarz, Warszawa 2017, s. 41 . 
także do tak istotnych z punktu widzenia beneficjentów dofinansowania kwestii związanych $\mathrm{z}$ odpowiednią ewidencją oraz rozliczeniem otrzymanych środków (art. 29). Są to cenne rozważania, ponieważ w samej ustawie nie uregulowano zasad prowadzenia wyodrębnionej ewidencji księgowej. Autorzy słusznie w tym aspekcie zauważają, że do środków pochodzących z Funduszu powinno się stosować reżimu prawnego właściwego dla środków z budżetowej dotacji celowej. Nie można więc ich swobodnie wydawać, skoro są przeznaczone na określone cele, a prawidłowo prowadzona ewidencja powinna uwzględniać nie tylko cel poniesionego wydatku, lecz także jego wysokość, datę poniesienia, sposób dokonania płatności, podmiot, któremu dokonano zapłaty czy rodzaj robót, za które zapłacono.

Zaletą komentarza jest też to, że nie pominięto w nim zagadnień mniej istotnych, uregulowanych $\mathrm{w}$ rozdziale 4 „Przepisy zmieniające, dostosowujące, przejściowe i końcowe". Bywa niekiedy, że w komentarzach do ustaw tego rodzaju regulacje nie są w ogóle omawiane, a przecież (zwłaszcza przepisy przejściowe i końcowe) mają z zasady bardzo duże praktyczne znaczenie. Tego błędu Autorzy komentarza nie popełnili.

W konkluzji niniejszej recenzji należy stwierdzić z całym przekonaniem, że mamy do czynienia $z$ klasycznym $w$ swej formie komentarzem do ustawy dotyczącej finansowania samorządowych inwestycji drogowych. Merytoryczny poziom prowadzonych rozważań świadczy o dużej wiedzy Autorów opracowania nie tylko sensu stricto w zakresie komentowanej ustawy, lecz także szerokiego obszaru, jakim są finanse publiczne. Mogę z całym przekonaniem stwierdzić, że komentarz napisany został przez specjalistów z tego zakresu, których zainteresowania i wiedza sięga daleko poza obszar wyznaczony komentowanym aktem. Wiedza ta została jednak wykorzystana w taki sposób, aby przede wszystkim w przystępny sposób zaprezentować, niekiedy bardzo skomplikowane, zasady dofinansowywania inwestycji drogowych realizowanych przez jednostki samorządu terytorialnego.

Mając na uwadze stan prawny, który uwzględniono w komentarzu oraz dokonane po jego opublikowaniu zmiany w ustawie, której nadano nazwę „, Rządowym Funduszu Rozwoju Dróg", postulować należy uzupełnienie opracowania o te nowe kwestie. Samo w sobie jest doskonałą bazą do kolejnego wydania komentarza, który uwzględni rozszerzenie zakresu przedmiotowego zadań finansowanych z Funduszu. Jestem pewien, że te nowe części będą tak samo interesujące i na tak samo wysokim merytorycznym poziomie jak recenzowana przeze mnie praca. 